\title{
Moderna Visão do Indiciamento Penal no Curso Investigativo ${ }^{1}$
}

\author{
Marcelo Zago Gomes Ferreira \\ Polícia Civil do Distrito Federal - Brasil

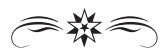

\section{RESUMO}

Trata-se de um ensaio teórico cujo escopo é, utilizando o método dialético, apresentar uma moderna visão à figura do indiciamento penal realizada no curso investigativo, a qual, com as devidas vênias, aparenta, sob o prisma da literatura hodierna, incompleta ou superada. A partir de pesquisa bibliográfica e jurisprudencial, passa-se pela construção da teoria denominada tríplice opinio delicti, a qual corrige parcialmente o enfoque minimalista conferido ao tema. Por fim, com ênfase constitucional-garantista e sob a ótica da Lei $n^{\circ}$. 12.830/13 - que trata da investigação criminal conduzida pelo Delegado de Polícia - propõe-se um novo conceito a esse instituto de relevantes consequências jurídicas.

Palavras-Chave: Indiciamento. Lei n . 12.830/13. Opinio delicti policial.

\section{INTRODUÇÃ̃O}

A persecução criminal pode ser dividida em duas fases bem delimitadas, sendo a primeira delas exercida por meio do inquérito policial ou outro procedimento de investigação preliminar, os quais possuem como característica a mitigação do princípio contraditório - em razão do procedimento precipuamente inquisitorial - e a segunda materializada por meio do processo penal, que tem por base o sistema acusatório, cuja bilateralidade de audiência (contraditório) é corolário e abrangente, devendo gerar cognição exauriente do magistrado.

A fim de evitar a concentração de poder estatal em detrimento do cidadão - manobra típica dos Estados autoritários ${ }^{2}$ - a Constituição Fe-

1 Artigo científico apresentado à Academia Nacional de Polícia, como exigência parcial para a conclusão do Curso de Especialização em Ciências Policiais - Gestão da Investigação Criminal - Orientador: Me. Sandro Lúcio Dezan; Primeiro membro da banca: Me. Márcio Adriano Anselmo; Segundo membro da banca: Me. Franco Perazzoni.

2 Segundo o raciocínio garantista de Luigi Ferrajoli, a separação de poderes acompanha a evolução do Estado como garantidor de direitos. - cf. FERRAJOLI, Luigi. Direito e Razão: teoria do garantismo 
deral de 1988 definiu e dividiu perfeitamente as atribuições da persecução criminal em três funções de Estado: Estado-investigador, Estado-acusador e Estado-juiz, todas harmônicas, entretanto sem grau de subordinação entre $\mathrm{si}^{3}$, no afã do descobrimento da verdade dos fatos ${ }^{4}$ e concretização de possível jus puniendi estatal - sem descuidar, em nenhum momento, da preservação dos direitos e garantias dos envolvidos, preservação esta legitimadora da função de persecução criminal. ${ }^{5}$

O aspecto garantista da separação das atribuições que compõem a persecução criminal é reforçado na doutrina nacional, por exemplo, pelo estudo de Vanessa Pitrez de Aguiar Corréa, a qual aduz, in verbis: "A divisão pelo Estado dos poderes a ele próprio conferidos é medida fundamental para sua própria limitação (sic) conferindo, assim, segurança jurídica ao cidadão e garantindo a manutenção do Estado Democrático de Direito". (CORRÉA, 2009, p. 51)

Destarte, a atuação desses entes estatais envolvidos no jus persequendi é exercida por meio de atos oficiais, os quais, encerrada determinada fase (investigativa, acusatória e julgadora) geram um provimento de Estado 7 .

O presente estudo tem por finalidade rememorar a visão clássica acerca do instituto do indiciamento penal e, a par disto, analisar, definir o conceito e estabelecer as características limites deste provimento do Estado-investigação - ou ausência dele - à luz da Lei nº. 12.830/13, que trata da investigação criminal conduzida pelo delegado de polícia, e

penal. Trad. Ana Paula Zomer et al. São Paulo: Revista dos Tribunais, 2002, p. 617-619.

3 Vide art. $144, \$ 1^{\circ}$, I; art. $144, \$ 4^{\circ}$; art. 129 , I; art. 92 e ss., todos da CF.

4 Sobre verdade na investigação - cf. PEREIRA, Eliomar da Silva. Teoria da investigação criminal. Lisboa: Almedina, 2010, p. 93-140.

5 Manuel Valente sustenta que a cientificidade da investigação criminal, como integrante do processo de persecução penal, se justifica e dirige-se à garantia dos direitos humanos - cf. VALENTE, Manuel Monteiro Guedes. A cientificidade da actuação policial como garante dos direitos humanos. Revista Brasileira de Ciências Policiais. v. 1 - n. 1. Brasília: Academia Nacional de Polícia, 2010, p. 13-20. No mesmo diapasão, Paulo Valente afirma que realizar o trabalho policial de maneira mais científica traz mais legitimação à polícia e a suas atividades, em virtude da possibilidade de mais informação para a sociedade. cf. VALENTE, Paulo Gomes. A actividade policial como ciência. Revista Brasileira de Ciências Policiais. v. 1 - n. 2. Brasília: Academia Nacional de Polícia, 2010, p. 105-125.

6 No mesmo sentido o parecer de José Afonso da Silva em consulta formulada pelo IBCCrim. Disponível em http://s.conjur.com.br/dl/parecer-jose-afonso-silva-pec-37.pdf. Acesso em: 17 jul. 2013. No referido parecer, o autor afirma que a Constituição Federal não previu poderes investigatórios ao Ministério Público, embora o tema seja controverso.

7 Por "provimento de Estado" entenda-se o dever-poder da Administração Pública em manifestar-se. 
da teoria da "tríplice opinio delicti" trabalho acadêmico, concebendo-se uma moderna visão do indiciamento penal no curso investigativo. ${ }^{9}$

\section{DesENVOLVIMENTO}

Há décadas, a escassa literatura acerca do tema em tela era praticamente uníssona na crítica da ausência de previsão legal do instituto do indiciamento, porquanto geradora de consequências jurídicas relevantes ao indiciado. ${ }^{10,11}$ Neste sentido, Lopes Júnior e Gloeckner (2013, p. 431) afirmam: "Entre os maiores problemas do inquérito policial está a ausência de indiciamento formal, com momento e forma estabelecidos em lei". Com razão, em parte, criticam os autores - em nota de rodapé - a ausência da prática de ato formal diante da lacuna legislativa: "[...] o indiciamento deve ser um ato formal, mas, na prática não é. Assim, quando reclamamos de falta de um indiciamento formal, estamos fazendo alusão ao plano da efetividade, frisando o prejudicial distanciamento entre normatividade e a efetividade" (LOPES JR; GLOECKNER, 2013, p. 431). No mesmo sentido, posicionava-se Pitombo (1983), a título de proposta de lege ferenda.

A lacuna legal foi parcialmente corrigida com o advento da Lei $\mathrm{n}^{\circ}$. 12.830 , de 20 de junho de 2013, que dispõe sobre a investigação criminal conduzida pelo delegado de polícia. Em seu art. $2^{\circ}, \$ 6^{\circ}$, a citada lei reza:
Art. $2^{\circ}$ - As funções de policia judiciária e a apuração de infraçôes penais exercidas pelo delegado de polícia são de natureza jurídica, essenciais e exclusivas de Estado.
[...]
$\$ 6^{\circ} \mathrm{O}$ indiciamento, privativo do delegado de polícia, dar-se-á por ato fundamentado, mediante análise técnico-jurídica do fato, que deverá indicar a autoria, materialidade e suas circunstâncias. ${ }^{12}$

8 Cf. nota de rodapé no 19.

9 Exclui-se do escopo deste estudo a análise das peculiaridades do indiciamento advindo do flagrante delito.

10 Acerca dos efeitos jurídicos da condição de indiciado, vide tópico 2.3 infra.

11 Em posição oposta, Fauzi Hassan Chouke entende que o indiciamento não se sustenta legalmente, além de ser desnecessário, porquanto não possui consequências relevantes no âmbito endoprocessual. Cf. CHOUKE, Fauzi Hassan. Garantias constitucionais na Investigação Criminal. São Paulo: Revista dos Tribunais, 1995.

12 BRASIL. Lei $\mathbf{n}^{\circ}$. 12.830, de 20 de junho de 2013. Disponível em http://www.planalto.gov.br/ ccivil_03/_ato2011-2014/2013/lei/112830.htm Acesso em: 22 ago. 2013. 
À luz da importante inovação legislativa, necessário se faz apresentar as definições sugeridas pela literatura e, de forma despretensiosa, após apresentar a teoria da tríplice opinio delicti e agregar um estudo pormenorizado acerca das características do instituto do indiciamento formal, propor atualizado conceito ao instituto.

\section{I. VISÃO CONCEITUAL CLÁSSICA DO INDICIAMENTO}

Pouco se produz no âmbito nacional acerca do tema em apreço, seja em razão do simplório valor conferido pelos estudiosos aos institutos do inquérito policial; seja em razão do desconhecimento dos procedimentos práticos de polícia judiciária ou, por fim, seja pela ausência da acepção do instituto como tal no direito comparado. Em que pese esta constatação, alguns estudiosos conceituam o instituto. Traz-se à colação alguns conceitos apresentados pela literatura a fim de situar o leitor.

Na visão de Pitombo (1983), o indiciamento demonstra o encontro de um "feixe de indícios convergentes", que apontam o suposto autor da infração penal. Almeida (1913, apud PITOMBO, 1983, p. 313) afirma que, assim como o exame de corpo de delito aponta a materialidade, o indiciamento aponta a autoria provável.

Na doutrina de Edilson Bonfim:

o indiciamento éo ato pelo qual o delegado atribui a alguém a prática de uma infração penal, buscando indícios suficientes e convergentes de autoria. O investigado, inicialmente mero suspeito da prática do crime, após o indiciamento passa a ser considerado o provável autor, condição que obviamente poderá ser elidida posteriormente, durante o inquérito ou já após o ajuizamento da ação penal, com a produção de prova favorável ao indiciado. (BONFIM, 2010, p. 161).

Para Leonardo Barreto Garcia, o indiciamento é "a comunicação formal feita pelo Estado ao investigado de que, a partir daquele momento ele passa a ser o principal suspeito da prática do crime, motivo pelo qual o foco das investigações volta-se contra ele”. (GARCIA, 2010, p. 120)

Dos conceitos anteriores, pouco divergem Nestor Távora e Rosmar Alencar ao afirmarem que o indiciamento "é a informação ao suposto autor a respeito do fato objeto das investigações. É a cientificação ao suspeito de que ele passa a ser o principal foco do inquérito". (TÁVORA; ALENCAR, 2009, p. 92). 
Eduardo Cabette, afirma, in litteris, que:

O indiciamento é a ato pelo qual a Autoridade Policial, no curso do inquérito policial, aponta determinado suspeito como autor de uma infração penal. Portanto, para que haja indiciamento, mister se faz a comprovação da materialidade da infração e indícios convincentes de que o investigado é seu autor. Como logo se percebe, trata-se de "ato privativo da Autoridade Policial". (CABETTE, 2013).

Talvez o conceito mais robusto acerca do tema seja da lavra de Sannini Neto (2012), que, em artigo publicado antes da Lei $\mathrm{n}^{\circ}$. 12.830/13, conceituava indiciamento como sendo:

[...] um ato formal, de atribuição exclusiva da Autoridade de Policia Judiciária, que ao longo da investigação forma seu livre convencimento no sentido de que há indícios minimos de que um suspeito tenha praticado determinado crime. A partir desse ato, o indiciado passa a ser o foco principal das investigaçôes. Trata-se, na verdade, de uma formalidade que fundamenta as conclusões do Delegado de Polícia acerca da autoria criminosa e, por isso, deve ser precedido de um despacho. Ademais, o indiciamento constitui uma garantia para a ampla defesa do investigado, que a partir de então passa a ter ciência do seu status dentro da persecução penal. Fazendo uma analogia com o auto de prisão em flagrante, podemos afirmar que o indiciamento funciona como uma nota de culpa.

Após situar o leitor através da colação dos conceitos alhures, pode-se prosseguir na construção da visão através de novo prisma teórico e na análise das características intrínsecas ao instituto do indiciamento.

\subsection{DA CONCEPÇÃO DO INDICIAMENTO ANTE A TEORIA DA TRÍ- PLICE OPINIO DELICTI}

Como salientado na introdução, o procedimento de persecução penal é formada por duas fases distintas, cada qual com suas peculiaridades, princípios e sistemas. Ademais, é possível verificar, nas ações penais públicas $^{13}$, a atuação - com exclusividade estatal - de três envolvidos: o investigador, o acusador ${ }^{14} \mathrm{e}$ o julgador.

13 Com exceção das situações que envolvem investigação de pessoas com foro por prerrogativa de função.

14 O Ministério Público acumula a função de Estado-acusação e de custos legis, ou seja, fiscal da lei. 
A fase investigativa da persecução criminal, marcada pelo procedimento inquisitorial ${ }^{15}$, é, via de regra, exercida pelas polícias civis e federal, que envidam esforços para a apuração da materialidade do fato definido como infração penal, sua autoria e circunstâncias em que ocorreram. Encerrado esse procedimento, o Estado-investigação, presentado pelo Delegado de Polícia, emite um provimento, materializado pelo indiciamento (ou ausência dele).

Neste sentido, pode-se sustentar que, assim que investigação policial alcança o aparente êxito, garantindo a certeza de materialidade, circunstâncias do fato e revelando indícios em desfavor de algum suspeito, indicando-o por dedução lógica como o provável autor da infração penal, o Delegado de Polícia deve manifestar nos autos sua opinio delicti policial positiva. Em contrapartida, caso entenda a Autoridade Policial que as diligências efetuadas não são suficientes para conferir probabilidade de autoria, deve o Delegado de Polícia não proceder ao indiciamento do suspeito ${ }^{16}$, sendo essa inação a materialização da opinio delicti policial negativa.

$\mathrm{O}$ indiciamento, portanto, pode ser definido preliminarmente como um provimento estatal que materializa a opinio delicti policial positiva, ou seja, aponta determinado suspeito como provável autor da infração penal. Essa opinião, no entanto, não vincula o Estado-acusação, que exercerá a opinio delicti ministerial através de seu provimento (denúncia ou promoção de arquivamento); o qual, por sua vez, não vincula o Estado-juiz de exercer seu julgamento (opinio delicti judicial), condenando ou absolvendo o acusado conforme as provas colhidas durante a instrução criminal sob o crivo do contraditório.

Em suma, pode-se afirmar que, sendo três os entes envolvidos na persecução criminal, a opinião acerca da existência, autoria e circunstâncias dos fatos serão emitidas individualmente pelos detentores legítimos dessas atribuições - em um juízo não vinculante ao posterior integrante do sistema ${ }^{17}$. Com efeito, o Estado-investigador emitirá seu

15 Sobre a necessidade de procedimento inquisitorial na fase do inquérito policial, vide nota de rodapé n. 22 do presente estudo.

16 Também no sentido de que não havendo probabilidade não deve o suspeito ser indiciado: (LOPES JÚNIOR; GLOECKNER, 2013)

17 Destaque-se que nos posicionamos pela necessidade de motivação em todos os citados provimentos estatais - sobretudo nos casos de discordância, ou seja, casos em que não se pode valer a opinio 
juízo de valor, de forma técnico-jurídica, a respeito do fato investigado (materialidade, autoria e circunstâncias) através do indiciamento ${ }^{18}$; bem como o fará o Estado-acusação através da denúncia; como, outrossim, fará o Estado-juiz através da sentença. A essa sucessão de valorações, denomina-se teoria da tríplice opinio delicti. ${ }^{19,20}$

Necessário perceber que, na medida em que a persecução criminal prossegue e é realizado um juízo de valor acerca do fato pelo órgão estatal que exerce sua atribuição constitucional (opinio delicti ${ }^{2 I}$ ), aumenta-se o deferimento de garantias do cidadão investigado/acusado para a próxima análise, caso persista a imputação do fato criminoso sobre ele. ${ }^{22}$

A afirmação supratranscrita é evidente ao se imaginar hipoteticamente um caso de persecução penal: ocorrido um fato, inicialmente é realizada uma análise pelo delegado de polícia acerca da possibilidade, em tese, de ser um relevante penal. Uma vez verificada esta condição, instaurar-se-á inquérito policial ou outro procedimento investigatório a fim de apurar materialidade, autoria e circunstâncias do fato. Nesse ponto, como em muitos casos sequer há investigado, evidente a impossibilidade de garantir a ele seus direitos constitucionais. ${ }^{23}$

delicti posterior dos próprios fundamentos da anterior. Entendemos que o julgador deve vislumbrar os mais variados argumentos em busca da melhor decisão possível, de forma que as hipóteses sejam confirmadas ou refutadas à luz do sistema jurídico.

18 Ou ausência dele.

19 Na mesma linha de raciocínio, Pitombo (1983) quando afirma que o indiciamento "consiste, pois, em rascunho de eventual acusação; do mesmo modo que as denúncias e as queixas também se manifestam quais esboços da sentença penal."

20 Os termos tríplice opinio deliciti e opinio delicti judicial foram utilizados por Wilmar Costa Braga e mencionado em palestra ministrada no auditório do Departamento de Polícia Especializada (DPE), Brasília/DF, em 18/08/2010. Já a expressão opinio delicti policial adveio da originária opinio delicti da autoridade policial, mencionada em CINACCHI Jr., Higino. Indiciamento. Opinio delicti da autoridade policial?. Boletim da Associação dos Juízes Federais de São Paulo e Mato Grosso do Sul (AJUFESP), jan./fev. 2000, p. 11.

21 Não concordamos, portanto, que o termo opinio delicti deva ser aplicado exclusivamente à manifestação ministerial, sendo esta apenas uma das espécies de opinio delicti, juntamente com a opinio delicti policial e opinio delicti judicial.

22 Concordamos com a opinião de Lopes Jr (2006) que concebe o processo penal como um sistema escalonado, progressivo ou regressivo da culpabilidade.

23 Esse é um dos motivos pelo qual a investigação criminal necessariamente será inquisitorial como método; ora, impossível estabelecer uma relação entre sujeitos se um deles (o autor do fato) se mantém, por escolha, alheio à investigação. Vide PEREIRA, Eliomar da Silva. Teoria da investigação criminal. Lisboa: Almedina, 2010, p. 183. 
Através de diligências efetuadas por determinação da Autoridade Policial ${ }^{24}$, pode recair suspeita da prática da infração sobre certo indivíduo. Neste ponto, como já existe pessoa investigada, seus direitos constitucionais devem ser respeitados, a exemplo da garantia de seu direito ao silêncio e reserva de jurisdição para determinadas medidas. ${ }^{25}$ Neste ponto, há somente possibilidade da prática delitiva por determinado indivíduo.

Com o desenvolver do procedimento, utilizando-se de técnicas legítimas de investigação (técnicas policiais ordinárias, técnicas juridicamente condicionadas e técnicas destinadas ao crime organizado ${ }^{26}$ ), pode-se chegar à probabilidade do cometimento da infração, através da coleção de indícios. ${ }^{27}$

Ao identificar a ocorrência da citada probabilidade da prática delitiva, o Delegado de Polícia deve, de acordo com sua convicção técnico-jurídica $^{28}$, indiciar o investigado, o qual passará à nova condição jurídica: a de indiciado - fato que gerará, além dos efeitos inconvenientes apontados no decorrer deste trabalho, o reforço de maiores garantias de direito, a exemplo de receber comunicação expressa acerca de seus direitos constitucionais, dentre eles, o de permanecer em silêncio, não produzir provas contra si mesmo (nemo tenetur se detegere) e ser assistido por advogado (art. $5^{\circ}$, LXIII, CF). ${ }^{29}$ Neste sentido, o indiciamento pode ser entendido como um aviso de garantia do cidadão. (MANZANO, 2010).

Findo o procedimento investigativo, o Ministério Público exercerá, com independência - ou seja, de maneira não vinculada ao entendi-

24 Ressalte-se que há diligências que fogem ao crivo discricionário do Delegado de Polícia, a exemplo do exame de corpo de delito em crimes que deixam vestígios (arts. 158 e 184 do Código de Processo Penal) e das diligências requisitadas pelo juiz e pelo Ministério Público (art. 13, II, do Código de Processo Penal)

25 Cf art. $5^{\circ}$, X; XI; XII e LXIII, todos da Constituição Federal.

26 Segundo Pereira (2010), as primeiras são as técnicas em geral utilizadas pelos policiais em suas rotinas diuturnas de atividade; já as segundas são técnicas previstas em legislação processual penal, com previsão expressa de requisitos mínimos - com ou sem autorização judicial; as últimas são exclusividades investigativas previstas na Lei $n^{\circ} .12 .850 / 13$, como ação controlada, infiltração etc.

27 "A palavra indício advém do latim "índex" (dedo indicador) que aponta para algo ou alguém. Segundo o artigo 239 do Código de Processo Penal, indício é a circunstância conhecida e provada que, tendo relação com o fato, autorize, por indução, concluir-se a existência de outra ou outras circunstâncias."

28 Acerca da expressão "técnico-jurídica” falar-se-á no tópico 2.3.1 doravante.

29 Entendemos que ao indiciado deve haver comunicação expressa (escrita ou verbal) acerca de seus direitos constitucionais - Aviso de Miranda - pelo delegado de polícia. Cf. nota de rodapé n 57. 
mento anterior - sua opinio delicti, denunciando o indiciado ou promovendo o arquivamento dos autos. ${ }^{30} \mathrm{Com}$ a decisão judicial favorável ao recebimento da denúncia do parquet, o indivíduo passa à condição de réu, sofrendo nova alteração de status jurídico.

Note-se que, em razão do princípio contraditório norteador do processo penal, o réu recebe nova carga de direitos e garantias, a exemplo da indisponibilidade de defesa técnica através de advogado ou defensor público $^{31}$, possibilidade de ampla defesa e necessidade de ser intimado acerca dos atos do processo.

Sob outro prisma, o raciocínio proposto lembra, em analogia, uma série de filtros cuja imputação tenta ultrapassar; cada etapa vencida gera nova condição jurídica e maiores garantias ao indivíduo supostamente infrator, estreitando o filtro, à medida que legitima o possível exercício do juspuniendi. ${ }^{32}$

Posto esse arcabouço teórico, passa-se à análise das demais características pertinentes ao tema a fim de propor, ao desfecho, um atual conceito de indiciamento penal.

\subsection{PROPOSTA DE UM MODERNO CONCEITO DE INDICIAMENTO PENAL ${ }^{33}$}

A palavra "conceito" pode ser definida como "Representação de um objeto pelo pensamento, por meio de suas características gerais" (FERREIRA, 1986, p. 445). Com efeito, segundo Dahlberg (1978), a formação dos conceitos é obtida através da reunião e compilação de enunciados verdadeiros e características acerca de determinado objeto. Destarte, neste tópico evidenciar-se-ão as características e enunciados do indiciamento penal a fim de propor, ao desfecho, uma contemporânea definição.

\footnotetext{
30 Vide art. 129, I, da Constituição Federal; art. 1º, parágrafo único, da Lei nº $8625 / 93$ e art. $4^{\circ}$ da LC $75 / 93$.

31 Ver art. 261, do Código de Processo Penal.

32 No mesmo sentido, Cf. Sannini Neto (2012).

33 O título deste tópico revela a despretensão do autor em estabelecer "o conceito" de indiciamento penal hodierno, mas sim a "proposta" de "um conceito".
} 
Moderna Visão do Indiciamento Penal no Curso Investigativo

\subsubsection{REFLEXóES TEÓRICAS BÁSICAS PARA ALCANCE DO CONCEITO}

Rememorando o esforço teórico transcrito no tópico 2.2, concluiu-se que o indiciamento é um provimento estatal que materializa a opinio delicti positiva do Estado-investigador, representado pelo Delegado de Polícia, nos termos do art. $144, \$ 4^{\circ}$, da CF. ${ }^{34}$ Com efeito, nos termos do art. $2^{\circ}, \$ 6^{\circ}$, da Lei $n^{\circ} .12 .830 / 13$, é forçoso concluir que a Autoridade Policial é titular exclusivo da opinio delicti policial, sendo ilegítima qualquer ingerência em sua valoração técnico-jurídica.

Nesse diapasão, não há de ser admitida a determinação de indiciamento por superior hierárquico, magistrado ou membro do Ministério Público, gerando tal "requisição" constrangimento ilegal. ${ }^{35}$ No mesmo sentido, $\mathrm{Nucci}^{36}$, Rogério Romano ${ }^{37}$, Leonardo Garcia ${ }^{38}$, dentre outros. Como bem salienta Saninni Neto (2012), caso o magistrado determinasse o indiciamento, haveria grave ofensa ao sistema acusatório e ao princípio da imparcialidade, pois o julgador estaria antecipando sua decisão de mérito ${ }^{39}$. Já no caso de requisição do membro do parquet, ferido estaria o art. 16 do Código de Processo Penal, o qual impõe restrição à devolução dos autos do inquérito policial ao delegado de polícia apenas ao cumprimento de diligências imprescindível ao oferecimento da denúncia. ${ }^{40}$

Ademais, considerando que o indiciamento é uma manifestação estatal que parte de um raciocínio de silogismo lógico qualificado pela exegese jurídica, sensível é a interferência de outro ente da persecução criminal no convencimento da Autoridade Policial.

\footnotetext{
34 Através da interpretação sistemática, entendemos que o mesmo raciocínio se aplica aos Delegados de Polícia Federal.

35 Vide STF - HC 35.639-SP, Relator Ministro José Arnaldo Fonseca, 21/10/2004.

36 Cf. NUCCI, Guilherme de Souza. Manual de Processo Penal e Exercução Penal. São Paulo: Revista dos Tribunais, 2006, p. 139.

37 Cf. ROMANO, Rogério Tadeu. O PLC 132 e o novo indiciamento. Disponível em http://www.jfrn. gov.br/institucional/biblioteca/doutrina/doutrina317-o-plc-132-e-novo-indiciamenteo.pdf. Acesso em: 20 ago. 2013.

38 Cf. GARCIA, Leonardo de Medeiros. Processo Penal. Salvador: Juspodivm, 2010, p. 120.

39 Vide STF - HC 115.015-SP, Relator Ministro Teori Zavascki, 27/08/2013.

40 Como salientado supra, a falta de indiciamento não vincula a opinião ministerial e é prescindível para o oferecimento da denúncia.
} 
Em outras palavras, o indiciamento é o entendimento do Delegado de Polícia acerca da materialidade, circunstâncias e, sobretudo, autoria de um fato criminoso, analisando os indícios revelados através da investigação, sob a premissa preliminar da legislação penal material e sua interpretação. Destarte, trata-se de um ato pessoal do referido agente público $^{41}$, não sendo possível a determinação por terceiro. A corroborar com o exposto, Rezende (2013) leciona:

A independência do delegado de polícia para indiciar ou instaurar o inquérito policial, conforme o seu juizo de tipicidade, se coaduna com o Estado Democrático de Direito e representa uma garantia do investigado. Evita o direcionamento de investigaçôes e assegura que o inquérito policial cumpra a sua finalidade: a busca da verdade real (a prova deve ser produzida imparcialmente, não podendo ser desprezadas aquelas que sejam favoráveis ao investigado).

À luz do exposto, entendemos que a Autoridade Policial age com independência funcional e de acordo com seu livre convencimento, em que pese tenha sido vetado o $\$ 3^{\circ}$ do art. $2^{\circ}$ da Lei $n^{\circ} .12 .830 / 13$, que assim dispunha:

$\$ 3^{\circ} O$ delegado de policia conduzirá a investigação criminal de acordo com seu livre convencimento técnico-jurídico, com isenção e imparcialidade. ${ }^{42}$

Com efeito, aponta Dezan (2013) que o referido veto, de modalidade política, é irrelevante no contexto da autonomia investigativa, porquanto a Administração Pública deverá emitir sua decisão com base na Lei e no Direito, conforme se aduzirá doravante ${ }^{43}$. Outrossim, o veto presidencial $^{44}$, por ser de coalizão (baseado na contrariedade do inte-

41 Razão pela qual o despacho de indiciamento deve conter verbos na primeira pessoa do singular.

42 BRASIL. Lei $\mathbf{n}^{\circ}$. 12.830, de 20 de junho de 2013. Disponível em http://www.planalto.gov.br/ ccivil_03/_ato2011-2014/2013/lei/112830.htm Acesso em: 22 ago. 2013.

43 Dezan (2013) ainda ressalta o aspecto da própria Lei $n^{\circ}$. 12.830/12, porquanto, se há o dever de efetivar privativamente o indiciamento $\left(\$ 6^{\circ}\right.$, do art. $\left.2^{\circ}\right)$ e o dever de conduzir a investigação criminal (art. $1^{\circ}$ ), o delegado é responsável por exercer livremente análises técnico-jurídicas em todas as etapas da investigação materializada no inquérito policial. $\mathrm{O}$ interesse público requer essa atuação.

44 Razões do veto, segundo a presidência da república: ““ $\mathrm{Da}$ forma como o dispositivo foi redigido, a referência ao convencimento técnico-jurídico poderia sugerir um conflito com as atribuições investigativas de outras instituições, previstas na Constituição Federal e no Código de Processo Penal. Desta forma, é preciso buscar uma solução redacional que assegure as prerrogativas funcionais dos delegados de polícias e a convivência harmoniosa entre as instituições responsáveis pela persecução penal". Disponível em http://www.planalto. gov.br/ccivil_03/_Ato2011-2014/2013/Msg/VEP-251.htm. Acesso em: 17 jul. 2014. 
resse público) e não jurídico, deixou assente que o Delegado de Polícia possui autonomia ${ }^{45}$, isenção e imparcialidade, não como prerrogativas, mas sim como deveres.

A independência funcional sustentada já é reconhecida expressamente na Constituição do Estado de São Paulo, bem como na Lei Orgânica do Distrito Federal, veja-se:

\section{CONSTITUIÇÃO DO ESTADO DE SÃO PAULO}

Artigo 140 - A Policia Civil, órgão permanente, dirigida por delegados de policia de carreira, bacharéis em direito, incumbe, ressalvada a competência da União, as funçôes de polícia judiciária e a apuração de infrações penais, exceto as militares.

$\$ 3^{\circ}$ - Aos Delegados de Polícia é assegurada independência funcional pela livre convicção nos atos de policia judiciária. ${ }^{46}$

\section{LEI ORGÂNICA DO DISTRITO FEDERAL}

Art. 119. À Polícia Civil, órgão permanente dirigido por delegado de polícia de carreira, incumbe, ressalvada a competência da União, as funções de polícia judiciária e a apuração de infraçôes penais, exceto as militares.

\section{[...]}

$\$ 4^{\circ}$ Aos integrantes da categoria de delegado depolicia égarantida independência funcional no exercício das atribuiçôes de Policia Judiciária. ${ }^{47}$

Em razão de ser o indiciamento um ato privativo do delegado de polícia enquanto detentor de carreira jurídica ${ }^{48}$, embora haja divergência $^{49}$ entendemos não ser correta a confecção de termo circunstanciado (TCO) pela Polícia Militar ou pela Polícia Rodoviária Federal em crimes

45 Luiz Flávio Gomes e Fábio Scliar afirmam que a autonomia do Delegado de Polícia advém de uma interpretação à luz da Constituição Federal e não baseadas em normas infracionstitucionais e entendimentos anteriores à Carta de 1988. Cf. GOMES, Luiz Flávio e SCLIAR, Fábio. Investigação Preliminar, polícia judiciária e autonomia. Disponível em http://lfg.jusbrasil.com.br/noticias/147325/investigacaopreliminar-policia-judiciaria-e-autonomia-luiz-flavio-gomes-e-fabio-scliar. Acesso em: 17 jul. 2014.

46 SÃO PAULO. Constituição do Estado de São Paulo. Disponível em: http://www.al.sp.gov.br/repositorio/ legislacao/constituicao/1989/constituicao\%20de\%2005.10.1989.htm Acesso em: 22 ago. 2013.

47 DISTRITO FEDERAL. Lei Orgânica do Distrito Federal. Disponível em: http://www.fazenda. df.gov.br/aplicacoes/legislacao/legislacao/TelaSaidaDocumento.cfm?txtNumero=0\&txtAno=0\&tx tTipo=290\&txtParte $=$. Acesso em: 22 ago. 2013.

48 Cf. art. $2^{\circ}$, caput, da Lei $n^{\circ} .12 .830 / 13$.

49 No sentido da divergência, cf. FERGITZ, Andréia Cristina. Policial Militar: autoridade competente para lavratura do termo circunstanciado. Disponível em http://www.pm.sc.gov.br/artigos/2193. html. Acesso em: 17 jul. 2014. 
de menor potencial ofensivo. Ora, em que pese o regramento célere disciplinado pela Lei ${ }^{\circ} .9 .099 / 95$, é certo que a elaboração de TCO não deixa de trazer implícita a probabilidade de cometimento da infração penal, carecendo de uma análise jurídica do caso ${ }^{50}$, cabendo, a manifestação estatal, à Autoridade Policial ${ }^{51,52}$.

Entendemos que esta manifestação do Estado-investigador tem a natureza jurídica de ato administrativo, porquanto exercita prerrogativas da Administração Pública e produz efeitos jurídicos de fim público ${ }^{53}$, passíveis de controle de legalidade (MELO, 2010) ${ }^{54}$.

Segundo Manzano (2010), o indiciamento gera, ab initio, cinco consequências - quais sejam: 1) identificação do indivíduo nos termos da Lei $n^{\circ}$. $12.037 / 09$; 2) qualificação direta ou, na impossibilidade, indireta; 3) colheita de informações sobre a vida pregressa ${ }^{55}$; 4) interrogatório; e 5) inclusão do nome do indiciado em cadastro próprio da polícia ${ }^{56}$ - sendo definido por Bonfim (2010) como um ato complexo.

Tourinho Filho (2010), por sua vez, define o próprio indiciamento como o conjunto das providências supracitadas determinadas pela Autoridade Policial.

É certo que, em razão de o indiciamento gerar uma série de consequências, trata-se também de um ato constitutivo ${ }^{57}$, ou seja, faz nascer uma

50 Não comungamos de forma plena com o entendimento de Sannini Neto que sustenta a incompatibilidade da figura do indiciamento em crimes de menor potencial ofensivo. Segundo o autor, haveria desproporcionalidade entre os efeitos do indiciamento e a gravidade do crime. Cf. SANNINI NETO, Francisco. Indiciamento: ato privativo do delegado de polícia. Jus Navigandi, Teresina, ano 17, n. 3233. Disponível em: http://jus.com.br/artigos/21713. 8 maio 2012. Acesso em: 15 ago. de 2013. Acreditamos que, nestes casos, o indiciamento apenas não gera todos seus efeitos ordinários previstos no art. $6^{\circ}$ do Código de Processo Penal.

51 Ademais, a elaboração de TCO por órgãos estranhos à Polícia Judiciária afronta com clareza solar o art. 144, $\$ 4^{\circ}$ da Constituição Federal. Neste sentido cf. STF: ADI 3614-9, Rel. Originário Ministro GILMAR MENDES, Rel. para o Acódão Ministra CARMEN LÚCIA. TRIBUNAL PLENO, julgado em 20/09/2007, DJe 23/11/2007.

52 Corroborando o entendimento: cf. CABETTE, Eduardo Luiz Santos. Nova Lei n.12.830/13 Investigação pelo Delegado de Polícia. 23 jun 2013. Disponível em: http://atualidadesdodireito.com. br/eduardocabette/2013/06/23/nova-lei-12-83013-investigacao-pelo-delegado-de-policia/ Acesso em: 21 ago. 2013.

53 Primeira materialização do jus persequendi, garantidor mediato do direito à segurança pública (cf. art. 144, caput, da Constituição Federal).

54 Anselmo (2013) considera o indiciamento como sendo um ato administrativo com efeitos processuais.

55 A elaboração do boletim de vida pregressa do investigado demonstra o aspecto criminológico do ato do indiciamento.

56 Denominado como rol dos indiciados.

57 Anselmo (2013) defende que se trata de ato declaratório, uma vez que expressa a convicção de culpa 
situação jurídica nova (MELO, 2010), pois, além dos efeitos já citados, podem ser destacados os seguintes: a) incremento de garantias constitucionais, a exemplo de receber Aviso de Miranda ${ }^{58,59}$; b) será cassada a autorização de posse ou porte de arma ao indiciado por crime doloso ${ }^{60}$; c) afastamento do servidor público de suas funções sem prejuízo da remuneração nos casos envolvendo lavagem de capitais ${ }^{61}$; d) embaraços na avaliação de investigação social exigidas em concursos públicos ${ }^{62}$.

Em virtude das relevantes consequências jurídicas apontadas, a decisão de indiciamento deve ser fundamentada, demonstrando o Delegado de Polícia as razões pelas quais decidiu, móbil por que sustentamos que - a despeito de a fundamentação do indiciamento não estivesse prevista expressamente na legislação até a promulgação da Lei $n^{\circ}$. 12.830/13, exceto na Lei $n^{\circ} .11 .343 / 06^{63}$ - não era prescindível em qualquer cas ${ }^{64,65}$.

Outrossim, a motivação do ato é necessária a fim de garantir ao investigado o conhecimento inequívoco dos indícios que apontam em seu desfavor, permitindo-o a possibilidade de esclarecer determinados fatos em seu interrogatório. Na mesma esteira de raciocínio, Romano (2013) aduz:

Leve-se em conta que o indiciamento exerce função de garantia das liberdade individuais, uma vez que, por meio dele, o antigo suspeito toma conhecimento oficial do teor do inquérito, um verdadeiro constrangimento, razão pela qual está dentro do razoável exigir fundamentação quanto à autoria e materialidade do ato.

lato sensu do investigado pela autoridade policial.

58 Aviso de Miranda, originalmente conhecido como Miranda Rights, pode ser entendido como a leitura do direito do cidadão em permanecer em silêncio e não produzir provas contra si mesmo.

59 Este ponto já foi exposto no tópico 2.2, para onde remetemos o leitor.

60 Vide art. 67-A, $\$ 2^{\circ}$ do Decreto ${ }^{\circ} 5.123 / 04$.

61 Cf. art. 17-D da Lei $n^{\circ} .12 .683 / 2012$.

62 Entendemos como discutível o desligamento de candidato em concursos públicos na fase de avaliação social caso não haja trânsito em julgado da sentença penal condenatória (art. $5^{\circ}$, LVII, CF).

63 Cf. art. 52, I, da Lei nº. 11.343/06.

64 Ao reforço desse entendimento, Carvalho Filho (2009) leciona que a justificativa é indispensável a todo ato administrativo, seja ele discricionário ou vinculado.

65 Entendeu o STF que, em que pese razoável a fundamentação do indiciamento, por falta de previsão legal (anterior à Lei n ${ }^{\circ}$. 12.830/13), sua ausência não configurava constrangimento ilegal (HC 81648 , Relator(a): Min. ILMAR GALVĀO, Primeira Turma, julgado em 11/06/2002, DJ 23-08-2002 PP00092 EMENT VOL-02079-01 PP-00217). 
A fundamentação do ato serve ainda para permitir o controle judicial de eventuais indiciamentos abusivos e/ou precipitados, uma vez que estes causam constrangimento ilegal, passível de ser remediado através de habeas corpus $^{66}$. Assim têm apontado as decisões do STF, veja-se:

EMENTA: INQUÉRITO POLICIAL. Indiciamento. Ato penalmente relevante. Lesividade teórica. Indeferimento. Inexistência de fatos capazes de justificar o registro. Constrangimento ilegal caracterizado. Liminar confirmada. Concessão parcial de habeas corpus para esse fim. Precedentes. Não havendo elementos que o justifiquem, constitui constrangimento ilegal o ato de indiciamento em inquérito policial. (HC 85541, Relator(a): Min. CEZAR PELUSO, Segunda Turma, julgado em 22/04/2008, DJe-157 DIVULG 21-08-2008 PUBLIC 22-08-2008 EMENT VOL-02329-01 PP-00203 RTJVOL-0020503 PP-01207)- SEM GRIFOS NO ORIGINAL. ${ }^{67}$

Insta rememorar que o indiciamento traduz a ideia de probabilidade de autoria, que deve ser realizada com base nos elementos de investigação carreados aos autos do inquérito policial, motivo por que não é admissível o indiciamento de suspeito com base em meras impressões da Autoridade Policial, já havendo o Tribunal Regional da $3^{\text {a }}$ Região decidido nestes termos, veja-se:

REEXAME NECESSÁRIO EM HABEAS CORPUS. DELITO DE MOEDA FALSA. INDICLAMENTO FUNDADO EM IMPRESSÕES DA AUTORIDADE POLICIAL. FALTA DE ELEMENTOS PROBATÓRIOS MÍNIMOS. CONSTRANGIMENTO ILEGAL CARACTERIZADO. 1. As informaçōes prestadas pela autoridade impetrada evidenciam que a paciente foi indiciada com base nas impressóes do Delegado de Polícia Federal sobre o ocorrido, o qual considerou relevante o comparecimento espontâneo da vítima na delegacia de polícia e mencionou a necessidade de responsabilização dos estabelecimentos bancários nos casos em que os clientes reclamem do saque de cédulas falsas, imputando a responsabilidade à caixa do estabelecimento bancário, ora paciente, sem indicar elementos minimos de prova relativos à suposta autoria. 2. Nota-se que o indiciamento da paciente ocorreu de forma abusiva, sem amparo probatório minimo quanto ao dolo necessário para a realização da conduta típica. Portanto, resta caracterizado constrangimento ilegal passivel de correção por meio do

66 Denominados como desindiciamento coacto (TÁVORA;ALENCAR, 2009).

67 BRASIL. Supremo Tribunal Federal. HC 85541, Relator(a): Min. CEZAR PELUSO, Segunda Turma, julgado em 22/04/2008, DJe-157 DIVULG 21-08-2008 PUBLIC 22-08-2008 EMENT VOL-02329-01 PP-00203 RTJ VOL-00205-03 PP-01207 
Moderna Visão do Indiciamento Penal no Curso Investigativo

habeas corpus. 3. A D. Autoridade Policial expôs sua indignação, que nos parece legítima, quanto à postura dos bancos em relação ao crime de moeda falsa. Porém, tais consideraçôes não implicam na autoria do crime pela funcionária do banco, que salvo prova em contrário, que não há, não teria qualquer interesse em repassar nota falsa aos clientes do banco. Tudo indica que o fez por imperícia e o crime de moeda falsa não admite a modalidade culposa. 4. Desprovido o reexame necessário.

(REENEC 00037029320124036181, JUÍZA CONVOCADA LOUISE FILGUEIRAS, TRF3 - QUINTA TURMA, e-DJF3 Judicial 1 DATA:22/07/2013.) - SEM GRIFOS NO ORIGINAL. ${ }^{68}$

$\mathrm{Na}$ mesma linha de raciocínio deve ser vislumbrada a figura do indiciamento precoce, porquanto ainda não apoiado em indícios suficientes revelados pela investigação ${ }^{69}$. Neste ponto, forçoso reconhecer que é questionável a precisão técnica do indiciamento $a b$ initio $^{70}$, ou seja, aquele formulado no corpo da portaria inaugural, exceto se houver, em procedimento informativo anterior ${ }^{71}$, indícios claros de autoria e materialidade ${ }^{72}$.

Acerca da ausência legal de disciplinamento quanto ao momento adequado para o indiciamento, Lopes Jr e Gloeckner (2013, p. 5) tecem suas críticas:

O indiciamento deveria estar previsto no Código de Processo Penal de forma completa, exigindo um ato formal da polícia judiciária em momento determinado pela lei, bem como a comunicação do indiciado de modo a garantir o exercício dos direitos do sujeito.

Em face da lacuna legislativa, como aponta Avena (2009), parcela relevante da doutrina sustenta que o momento adequado para o indiciamento é o relatório, por ser a peça que encerra o inquérito policial e traz um resumo dos elementos indiciários levantados. Não concordamos com essa corrente pelo fato de considerarmos o interrogatório como um direito do indiciado em esclarecer os fatos segundo

68 BRASIL. Tribunal Regional Federal da Terceira Região. REENEC 00037029320124036181, JUÍZA CONVOCADA LOUISE FILGUEIRAS, TRF3 - QUINTA TURMA, e-DJF3 Judicial 1 DATA:22/07/2013.

69 Cf. BRASIL. Superior Tribunal de Justiça. HC 8.466/PR, Rel. Ministro FELIX FISCHER, QUINTA TURMA, julgado em 20/04/1999, DJ 24/05/1999, p. 183.

70 Também denominado indiciamento de plano

71 A exemplo do caso de desmembramento de inquérito policial existente.

72 Comunga do mesmo entendimento: cf. GULHERME, Ricardo Eduardo. Indiciamento no inquérito policial. Disponível em http://www.oabsp.org.br/noticias/2005/11/08/3288/. 8 nov 2005. Acesso em: 21 ago. 2013. 
seu prisma, após o conhecimento das razóes de ser o foco principal das investigações ${ }^{73}$. Nesse diapasão Lopes Jr e Klein (2013, p. 5):

"[...] o indiciamento realizado no final do inquérito policial, junto ao relatório elaborado pela autoridade policial, fere direitos do indiciado, pois não lhe permite o exercicio do direito de defesa com vistas à reversão da situação".

Ademais, por questões de ordem prática, haveria dificuldades em cumprirem-se os atos advindos do indiciamento (art. $6^{\circ}$, V, VIII e IX do Código de Processo Penal).

Entendemos que o momento adequado para o indiciamento não deve ficar rígido a um ou outro ato ou fase do inquérito policial, devendo ser avaliado casuisticamente pela Autoridade Policial presidente do feito, desde que realizado até o encerramento da investigação na esfera policial através do relatório final ${ }^{74,75}$. Uma vez reunidos os elementos aptos para a formação de sua convicção, deve o Delegado de Polícia proceder ao indiciamento do suspeito através de despacho ${ }^{76}$ fundamentado. Trata-se, pois, de ato vinculado. Nas palavras de Pitombo (1983, p. 313):

Indiciar alguém, como parece claro, não deve surgir qual o ato arbitrário, ou de tarifa, da autoridade, mas, sempre legitimo. Não se funda, também, no uso do poder discricionário, visto que inexiste, tecnicamente, a possibilidade legal de escolher entre indiciar ou não.

Em que pese nos posicionarmos pela natureza vinculada do ato de indiciamento, cabe ressaltar que a valoração da suficiência de indícios para gerar probabilidade de autoria é exclusiva do Delegado de Polícia

73 Lopes Jr e Gloeckner (2013) entendem que o interrogatório do investigado deve ser realizado antes do indiciamento.

$74 \mathrm{O}$ anteprojeto reforma do Código de Processo Penal estabelece, em seu art. $31, \$ 2^{\circ}$, que o limite temporal do indiciamento é o relatório final. Veja-se: art. $31, \$ 1^{\circ}$ - A condição de indiciado poderá ser atribuída já no auto de prisão em flagrante ou até o relatório final da autoridade policial. Cf. ANTEPROJETO DE REFORMA DO CÓDIGO DE PROCESSO PENAL. Disponível em: http://www.juareztavares.com/Textos/anteprojeto.pdf. Acesso em: 21 ago. 2013.

75 Vide STJ: MS 14.504/DF, Rel. Ministro JORGE MUSSI, TERCEIRA SEÇÃO, julgado em 14/08/2013, DJe 20/08/2013; HC 218.124/SP, Rel. Ministra MARILZA MAYNARD (DESEMBARGADORA CONVOCADA DO TJ/SE), QUINTA TURMA, julgado em 07/05/2013, DJe 10/05/2013; HC 218.124/SP, Rel. Ministra MARILZA MAYNARD (DESEMBARGADORA CONVOCADA DO TJ/SE), QUINTA TURMA, julgado em 07/05/2013, DJe 10/05/2013.

76 Segundo Di Pietro (2010, p. 234), “despacho é ato administrativo que contém as decisões das autoridades administrativas sobre assunto de interesse individual ou coletivo submetido à sua apreciação". 
presidente do feito. Em outras palavras, entendemos inadmissível a inércia da Autoridade Policial após a formação de sua conviç̧ão apoiada em elementos indiciários ${ }^{77}$.

Frise-se que o alcance jurídico da análise do conceito estratificado de crime efetuada pelo Delegado de Polícia deve se dar além da mecânica tipicidade formal, abrangendo, outrossim, além da tipicidade material, um juízo de ilicitude (rechtwidrigkeit) ${ }^{78}$ e culpabilidade ${ }^{79}$. Ora, se o Delegado de Polícia faz um juízo indiciário dos elementos referentes ao fato típico, com razão deve proceder ao mesmo juízo indiciário que aponte para a exclusão de ilicitude ou de culpabilidade, apenas realizando o indiciamento quando reunidos todos os elementos do conceito analítico de crime. Complementando o raciocínio, pode-se citar Conceição (2013) quando afirma:

[...] conforme disposiçãa do art. $144, \$ 4, d a C F$, bem como do $4^{\circ}$ do CPP, "apurar infraçôes penais e sua autoria".

Assim, deve o delegado apurar a autoria de infração penal, ou seja, autoria de "crime".

Caso o delegado entenda, juridicamente, analisando o fato sob o prisma de quaisquer teorias da tipicidade que adote (clássica, finalista, conglobante, imputação objetiva, constitucionalista do delito, etc.), que o 'autor' não praticou "crime", então a única solução será decidir pelo seu não-indiciamento, ou pela não lavratura do auto de prisão em flagrante, posto que não lhe compete indiciar "autor de fato ATÍPICO", nem "autor de conduta tipica e LÍCITA", mas sim "autor de infração penal", ou, em outras palavras, autor de crime.

Com efeito, não se pode conceber, em uma visão constitucional garantista, que o suspeito que tenha flagrantemente praticado o fato sob o manto de excludente de ilicitude ou de culpabilidade - não praticando fato

77 Em que pese esse posicionamento, em razão do evidente interesse público, entendemos como válido e legítimo o retardo do indiciamento caso esse ato imediato venha a comprometer o desfecho da investigação. A título de exemplo, pode-se sustentar que o Delegado de Polícia, como gestor da estratégia investigativa, necessita avaliar os riscos do indiciamento de apenas um dos suspeitos ao sucesso das diligências posteriores. Acreditamos, no entanto, que o indiciamento retardado deve ser fundamentado no relatório final com o escopo de dar transparência e legitimar a demora.

78 Neste sentido, cf. CABETTE, Eduardo Luiz Santos. O Delegado de Polícia e a análise de excludentes na prisão em flagrante. Jus Navigandi. Teresina, ano 16, n 3062, 19 nov 2011. Disponível em: http:// jus.com.br/artigos/20463 Acesso em: 20 ago. 2013.

79 Seguindo mesma posição, cf. CONCEIÇÃO, Fabrício Santis. Delegado é o "Senhor da Tipicidade Penal”? Disponível em: https://www.delegados.com.br/exclusivo/121-colunas/fabricio-desantis/792-delegado-de-policia-senhor-da-tipicidade-penal Acesso em: 20 ago. 2013. 
criminoso ${ }^{80}$, portanto - suporte os efeitos perniciosos do indiciamento. Anselmo (2013) aduz que parece ser esse o sentido da necessidade de "análise técnico-jurídica do fato" pela Autoridade Policial, nos termos do art. $2^{\circ}, \$ 6^{\circ}$ da Lei nº $12.830 / 13$, posição que aderimos.

Ademais, como aponta Dezan (2013), o inquérito policial - como procedimento administrativo em sentido amplo - também é regido pela Lei $n^{\circ}$. 9.784/99, a qual, em seu art. $2^{\circ}$, parágrafo único, inciso I, reza que deve haver atuação por parte da Administração Pública com base na Lei e no Direito, seja na Administração Pública federal ou estadual, nesta, por analogia.

A referida atuação conforme a Lei e o Direito ${ }^{81}$ trata-se dos princípios da legalidade e da juridicidade da atuação da Administração Pública, dos quais se extraem que há de se emitir no plano administrativo a melhor decisão possível, respeitada não só os limites legais formais, codificados e em visão singular, mas também a legislação de forma conglobada, além das manifestações metafísicas do direito, como os princípios, que, sem sombra de dúvidas, possuem efeito normativo.

A doutrina tem se referido a essa ampliação das barreiras da análise da legalidade estrita como bloco de legalidade, porquanto há uma extensão da visão míope da legalidade estrita, até os limites da ciência do Direito (DEZAN, 2013).

Dezan (2013) afirma que essa é a visão técnico-jurídica que se exige do delegado de polícia, nos dizeres da Lei n ${ }^{\circ}$. 12.830/12. Ipsis litteris:

[...] considera-se a investigação criminal, submetida aos prismas dos princípios da legalidade e da juridicidade da atuação da Administração Pública, fonte em que se obtêm os efeitos jurídicos alçados ao sistema da autonomia técnico jurídica do delegado de polícia na condução de apurações de ilícitos a partir da adoção da atuação instrutória não somente em conformidade com o estrito teor imediatamente normativo das prescriçôes legais, mas, em caráter de unicidade, sob a óptica da submissão à ciência do Direito, identificando o vinculo e o plexo de complementariedade formados entre ambos os institutos inferentes dos valores lei e Direito, como categorias distintas (DEZAN, 2013, p. 121).

80 Adota-se neste estudo a classificação finalista tripartite de delito.

81 Cabe rememorar a comezinha lição da hermenêutica jurídica: "a lei não contém palavras inúteis". Neste sentido, é por obvio que a atuação conforme a Lei é diversa da atuação conforme o Direito, possuindo esta última acepção carga valorativa, conforme aponta Dezan (2013). 
Dito isto, só se pode concluir que o Delegado de Polícia, na investigação criminal e na formação de opinio delicti policial, deve pautar sua análise no sistema normativo holístico, seja com base no texto legal, seja na carga valorativa advinda dos princípios.

Uma vez indiciado o antigo suspeito - com consequente conhecimento formal por ele acerca dos indícios que apontam em sua direção - este pode empenhar-se em esclarecer fatos, apresentar sua versão e tentar descontruir o convencimento da Autoridade indiciante. Ressalte-se que esta tentativa de influenciar de forma legítima no convencimento do Delegado de Polícia é um dos principais motivos do interrogatório policial.

A despeito de não haver disciplinamento legal na legislação nacional até a presente data, digna de elogios é a redação do articulo 118 da ley enjuiciamiento criminal da Espanha:

\section{Artigo 118.}

Toda persona a quien se impute un acto punible podrá ejercitar el derecho de defensa, actuando en el procedimiento, cualquiera que éste sea, desde que se le comunique su existencia, haya sido objeto de detención o de cualquiera otra medida cautelar o se haya acordado su procesamiento, a cuyo efecto se le instruirá de este derecho.

La admisión de denuncia o querella y cualquier actuación procesal de la que resulte la imputación de un delito contra persona o personas determinadas, será puesta inmediatamente en conocimiento de los presuntamente inculpados.

Para ejercitar el derecho concedido en el párrafo primero, las personas interesadas deberán ser representadas por Procurador y defendidas por Letrado, designándoseles de oficio cuando no los hubiesen nombrado por si mismos y lo solicitaren, $y$, en todo caso, cuando no tuvieran aptitud legal para verificarlo.

Si no hubiesen designado Procurador o Letrado, se les requerirá para que lo verifiquen o se les nombrará de oficio si, requeridos, no los nombrasen, cuando la causa llegue a estado en que se necesite el consejo de aquéllos o haya de intentar algún recurso que hiciese indispensable su actuación ${ }^{82}$.

Com efeito, seguindo na mesma linha, o anteprojeto de reforma do

82 ESPAÑA. Ley enjuiciamiento criminal. Gaceta $\mathrm{n}^{\circ} 260,17$ septiembre 1882 a gaceta $\mathrm{n}^{\circ} 283,10$ octubre 1882. Disponível em: http://www.boe.es/buscar/act.php?id=BOE-A-1882-6036. Acesso em: 22 ago. 2013 
Código de Processo Penal confere como direito do investigado à audiência com a autoridade competente, bem como faculta ao sujeito passivo da investigação a iniciativa de identificar fontes para sua defesa. Pela relevância das passagens, ipsis litteris:

Art. 13. É direito do investigado ser ouvido pela autoridade competente antes que a investigação criminal seja concluida.

Parágrafo único. A autoridade tomará as medidas necessárias para que seja facultado ao investigado o exercício do direito previsto no caput deste artigo, salvo impossibilidade devidamente justificada.

Art. 14. É facultado ao investigado, por meio de seu advogado ou de outros mandatários com poderes expressos, tomar a iniciativa de identificar fontes de prova em favor de sua defesa, podendo inclusive entrevistar pessoas.

Parágrafo único. As entrevistas realizadas na forma do caput deste artigo deverão ser precedidas de esclarecimentos sobre seus objetivos e do consentimento das pessoas ouvidas ${ }^{33}$.

Caso, a partir do interrogatório do indiciado ou pelo surgimento de novos fatos, a Autoridade Policial presidente da investigação se convença acerca do equívoco de sua decisão de indiciamento, deve retificá-la na primeira oportunidade ${ }^{84}$. A essa retificação dá-se o nome de desindiciamento. Este novo ato também exprime a opinio delicti policial negativa ${ }^{85} \mathrm{e}$ baseia-se no princípio de autotutela da Administração Pública. Acerca do citado princípio, Carvalho Filho (2009, p. 31) leciona:

A Administração Pública comete equivocos no exercício de sua atividade, o que não é nem um pouco estranhável em vista das múltiplas tarefas a seu cargo. Defrontando-se com esses erros, no entanto, pode ela mesma revê-los para restaurar a situação de regularidade. Não se trata apenas de uma faculdade, mas também de um dever, pois não se pode admitir que, diante de situações irregulares, permaneça inerte e desinteressada.

Destarte, a decisão de desindiciamento, que deve ser igualmente fundamentada, não configura nenhum demérito à Autoridade indiciante, ao revés, reveste-se em ato desprovido de vaidades, que demonstra o

83 Anteprojeto de reforma do Código de Processo Penal. Disponível em: http://www.juareztavares. com/Textos/anteprojeto.pdf. Acesso em: 21 ago. 2013.

84 Lopes Jr e Klein (2013) sustentam que o indiciamento é "situacional", posição da qual comungamos.

85 Sobre opinio delicti policial negativa, ver tópico 2.2 . 
compromisso do Delegado de Polícia com a legalidade. Realizado o ato, a Autoridade Policial deve determinar providências a fim de fazer cessar todos os ônus impostos pelo errôneo indiciamento, a exemplo da retirada do nome do indivíduo do rol dos indiciados ${ }^{86}$.

\subsubsection{UM MODERNO CONCEITO DE INDICIAMENTO PENAL}

À luz do estudo e reflexões apontados neste trabalho acadêmico, sem ter a pretensão de emitir a última palavra em qualquer dos assuntos e temas trabalhados e/ou sequer formular uma definição rígida, apresentamos a nossa proposta de um conceito para o indiciamento penal:

Indiciamento penal é o ato administrativo vinculado, fundamentado e privativo do delegado de polícia que - exprimindo sua opinio delicti policial positiva mediante análise técnico-jurídica - aponta determinado suspeito como provável autor de uma infração penal, submetendo-o a efeitos jurídicos relevantes e conferindo-lhe incremento de garantias.

\section{CONSIDERAÇốES FINAIS}

Em que pese a inexistência de vasto estudo acerca do indiciamento, a inovação trazida pela Lei $\mathrm{n}^{\circ} .12 .830 / 13$ foi valiosa neste campo, pois, além de encerrar a crítica realizada pelos estudiosos sobre a lacuna legal, aflorou a necessidade de reavaliação do tema sobre o enfoque moderno, a fim preencher crítico hiato acadêmico.

Através do presente artigo pôde-se concluir que o instituto em análise, muito além de consequências sociais, gera efeitos jurídicos relevantes, dentre eles, indesejáveis ônus. Em razão disso, o delegado de polícia, titular exclusivo da opinio delicti policial, deve, em análise técnico-jurídica apurada, identificar os elementos colhidos na investigação que preside, procedendo - de forma fundamentada - ao indiciamento do suspeito tão somente quando restar provável sua autoria, conferindo-lhe, ainda, o incremento de garantias advindas do ato.

86 Aderindo à mesma opinião, cf. SILVA, Márcio Alberto Gomes. Inquérito Policial: uma análise jurídica e prática da fase pré-processual. Campinas: Millenium, 2012, p.40. 
Destarte, assim como os demais institutos jurídicos, o indiciamento, como importante ato de polícia judiciária, deve ser interpretado por meio de uma visão atual e garantista, seguindo os ditames do Estado Democrático de Direito. Com efeito, a visão moderna do indiciamento penal reitera o papel da Autoridade Policial como membro de carreira jurídica, essencial e exclusiva de Estado ${ }^{87}$, além de reafirmar sua função de primeiro garantidor de direitos do cidadão.

Marcelo Zago Gomes Ferreira

Delegado de Polícia Civil do Distrito Federal. Professor do Centro Universitário IESB e da Academia de Polícia Civil do Distrito Federal. Aluno do doutorado em Direito Penal na Universidade de Buenos Aires - UBA. Especialista em Ciências

Criminais pela Universidade Gama Filho/RJ. Pós-graduado em Gestão de Polícia Civil pela Universidade Católica de Brasília/DF. Pós-graduado em Ciências Policiais - Gestão de Investigação Criminal - pela Escola Superior de Polícia da Academia de Polícia Federal - ANP. Pós-graduando em Criminologia, Política Criminal e Segurança Pública pela UniverSidade Anhanguera. Revisor da Malha Curricular Nacional e professor convidado da Secretaria Nacional de Segurança Pública - SENASP. Autor do livro "Crime de Embriaguez ao

VOLANTE: INAPLICABILIDADE DO EXAME VISUAL COMO MEIO DE prova" - Editora Lexia. Co-Autor do livro "Reflexiones Sobre Derecho Latinoamericano" vol. 8 - Editora Livre Expressão.

\section{ABSTRACT}

\section{Modern Vision of Charger in Criminal Investigative Course}

This is a theoretical essay whose scope is using the dialectical method, present a modern vision to the figure of the criminal charger held in investigative course which, with appropriate bows, looks through the prism of literature present day, incomplete or superseded. From literature and jurisprudence research, we pass by the construction of the theory called triple delicti opinion, which partially corrects the focus given to the minimalist theme. Finally, with constitutionally guarantism and from the perspective of Law 12.830/13 emphasis - dealing with the criminal investigation conducted by Chief Officer - proposes a new concept to this institute relevant legal consequences

KEYwORDS: Charger. Law 12.830/13. Police delicti opinion.

87 Lei n ${ }^{\circ} .12 .830 / 13$ - Art. $2^{\circ}$. As funções de polícia judiciária e a apuração de infrações penais exercidas pelo delegado de polícia são de natureza jurídica, essenciais e exclusivas de Estado. 


\section{RERERÊNCIAS}

ALMEIDA, Joaquim Canuto Mendes de. Princípios Fundamentais do Processo Penal, 1913. In: PITOMBO, Sérgio Marcos de Moraes. O indiciamento como ato de polícia judiciária. Revista dos Tribunais, n. 577, p. 313-316.

ANSELMO, Márcio Adriano. “Art, $2^{\circ}, \$ 6^{\circ}$. O indiciamento, privativo do delegado de polícia, dar-se-á por ato fundamentado, mediante análise técnico-jurídica do fato, que deverá indicar a autoria, materialidade e suas circunstâncias”, In: DEZAN, Sandro Lúcio; PEREIRA, Eliomar da Silva (org). Investigação criminal conduzida por delegado de polícia: comentários à Lei 12.830/2013. Curitiba: Juruá, 2013

ANTEPROJETO DE REFORMA DO CÓDIGO DE PROCESSO PENAL. Disponível em: http://www.juareztavares.com/Textos/ anteprojeto.pdf. Acesso em: 21 ago. 2013.

AVENA, Norberto Cláudio Pâncaro. Processo Penal: esquematizado. São Paulo: Método, 2009.

BONFIM, Edilson Mougenot. Curso de Processo Penal. $5^{\text {a }}$ ed. São Paulo: Saraiva, 2010.

BRASIL. Lei $n^{\circ}$. 12.830, de 20 de junho de 2013. Disponível em http:// www.planalto.gov.br/ccivil_03/_ato2011-2014/2013/lei/112830. htm Acesso em: 22 ago. 2013.

. Supremo Tribunal de Federal. HC 85541, Relator(a): Min. CEZAR PELUSO, Segunda Turma, julgado em 22/04/2008, DJe157 DIVULG 21-08-2008 PUBLIC 22-08-2008 EMENT VOL02329-01 PP-00203 RTJ VOL-00205-03 PP-01207

Superior Tribunal de Justiça. HC 8.466/PR, Rel. Ministro FELIX FISCHER, QUINTA TURMA, julgado em 20/04/1999, DJ 24/05/1999, p. 183.

Tribunal Regional Federal da Terceira Região. REENEC 00037029320124036181, JUÍZA CONVOCADA LOUISE FILGUEIRAS, TRF3 - QUINTA TURMA, e-DJF3 Judicial 1 DATA:22/07/2013.

CABETTE, Eduardo Luiz Santos. Nova Lei n ${ }^{\circ} \mathbf{1 2 . 8 3 0 / 1 3 -}$ 
Investigação pelo Delegado de Polícia. 23 jun 2013.

Disponível em: http://atualidadesdodireito.com.br/ eduardocabette/2013/06/23/nova-lei-12-83013-investigacao-pelodelegado-de-policia/ Acesso em: 21 ago. 2013.

O Delegado de Polícia e a análise de excludentes na prisão em flagrante. Jus Navigandi. Teresina, ano 16, n 3062, 19 nov 2011. Disponível em: http://jus.com.br/artigos/20463 Acesso em: 20 ago. 2013.

\section{CARVALHO FILHO, José dos Santos. Manual de Direito}

Administrativo. 22a ed. Rio de Janeiro: Lumen Juris, 2009.

. Uma análise sobre a coerência da jurisprudência do STJ quanto ao tema do indiciamento intempestivo. Jus Navigandi, Teresina, ano 12, n. 1367, 30 mar. 2007. Disponível em: htpp://jus.com.br/ artigos/9667. Acesso em: 20 ago. 2013.

CINACCHI Jr., Higino. Indiciamento. Opinio delicti da autoridade policial?. Boletim da Associação dos Juízes Federais de São Paulo e Mato Grosso do Sul (AJUFESP), jan./fev. 2000, p. 11.

CONCEIÇÃO, Fabrício Santis. Delegado é o "Senhor da Tipicidade Penal”? Disponível em: https://www.delegados.com.br/ exclusivo/121-colunas/fabricio-de-santis/792-delegado-de-policiasenhor-da-tipicidade-penal Acesso em: 20 ago. 2013.

. Lavratura do auto de prisão em flagrante pelo delegado de Polícia com o advento da Lei 12.830/13. Disponível em: https:// delegados.com.br/juridicos/4253-lavratura-do-auto-de-prisao-emflagrante-pelo-delegado-de-policia-com-o-advento-da-lei-12-830-13 Acesso em: 21 ago. 2013.

CORRÉA, Vanessa Pitrez de Aguiar. O papel da polícia judiciário no Estado Democrático de Direito. Segurança Pública \& Cidadania. Vol. 2, n. 1. Brasília: Academia Nacional de Polícia, 2009, p. 39-54.

DAHLBERG, Ingetraut. Teoria do conceito. Ciência da Informação, Rio de Janeiro, v. 7, n. 2, p. 101-107, 1978.

DEZAN, Sandro Lúcio. “Art. $2^{\circ}, \$ 3^{\circ}$ (VETADO). O delegado de polícia conduzirá a investigação criminal de acordo com seu livre convencimento técnico-jurídico, com isenção e imparcialidade", In: DEZAN, Sandro Lúcio; PEREIRA, Eliomar da Silva (org). 
Investigação criminal conduzida por delegado de polícia: comentários à Lei 12.830/2013. Curitiba: Juruá, 2013

DI PIETRO, Maria Sylva Zanella. Direito Administrativo. 23a ed. São Paulo: Atlas, 2010.

DISTRITO FEDERAL. Lei Orgânica do Distrito Federal. Disponível em: http://www.fazenda.df.gov.br/aplicacoes/legislacao/legislacao/ TelaSaidaDocumento.cfm?txtNumero $=0 \& \operatorname{txt}$ Ano $=0 \& \operatorname{txt}$ Tipo $=29$ 0\&txtParte $=$. Acesso em 22 ago. 2013.

ESPAÑA. Ley enjuiciamiento criminal. Gaceta $n^{\circ} 260,17$ septiembre

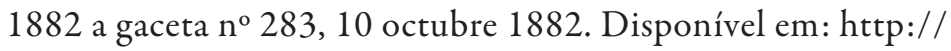
www.boe.es/buscar/act.php?id=BOE-A-1882-6036. Acesso em: 22 ago. 2013.

FERRAJOLI, Luigi. Direito e Razão: teoria do garantismo penal. Trad. Ana Paula Zomer et al. São Paulo: Revista dos Tribunais, 2002.

FERREIRA, Aurélio Buarque de Holanda. Novo dicionário da língua portuguesa. 2a ed. Rio de Janeiro: Nova Fronteira, 1986.

GARCIA, Leonardo de Medeiros. Processo Penal. Salvador: Juspodivm, 2010.

GULHERME, Ricardo Eduardo. Indiciamento no inquérito policial. Disponível em http://www.oabsp.org.br/ noticias/2005/11/08/3288/. 8 nov 2005. Acesso em: 21 ago. 2013.

LOPES JR, Aury.; GLOECKNER, Ricardo Jacobsen. Investigação preliminar no processo penal. São Paulo: Saraiva, 2013.

LOPES JR, Aury.; KLEIN, Roberta Coelho. O indiciamento e a Lei 12.830/2013: Um avanço, mas não o suficiente. Boletim IBCCRIM, ano 21, n² 249, ago. 2013, p.5-6.

LOPES JR, Aury. Sistemas de investigação preliminar no processo penal. $4^{a}$ ed. Rio de Janeiro: Lumen Juris, 2006.

MANZANO, Luis Fernando de Moraes. Curso de Processo Penal. São Paulo: Atlas, 2010.

MELO, Celso Antônio Bandeira. Curso de Direito Administrativo. 27 ed. São Paulo: Malheiros, 2010.

NUCCI, Guilherme de Souza. Manual de Processo Penal e Exercução Penal. São Paulo: Revista dos Tribunais, 2006. 
PEREIRA, Eliomar da Silva. Teoria da investigação criminal. Lisboa: Almedina, 2010.

PITOMBO, Sérgio Marcos de Moraes. $\mathrm{O}$ indiciamento como ato de polícia judiciária. Revista dos Tribunais, n. 577, 1983.

REZENDE, Bruno Titz de. $\mathrm{O}$ livre convencimento do delegado de polícia no indiciamento e na instauração do inquérito policial. Jus Navigandi, Teresina, ano 17, n. 3233. Disponível em: http://jus. com.br/artigos/20665. 16 dez. 2011. Acesso em 22 ago. de 2013.

ROMANO, Rogério Tadeu. O PLC 132 e o novo indiciamento. Disponível em http://www.jfrn.gov.br/institucional/biblioteca/ doutrina/doutrina317-o-plc-132-e-novo-indiciamenteo.pdf. Acesso em 20 ago. 2013.

SÃO PAULO. Constituição do Estado de São Paulo. Disponível em: http://www.al.sp.gov.br/repositorio/legislacao/constituicao/1989/ constituicao\%20de\%2005.10.1989.htm Acesso em: 22 ago. 2013.

SANNINI NETO, Francisco. Indiciamento: ato privativo do delegado de polícia. Jus Navigandi, Teresina, ano 17, n. 3233. Disponível em: http://jus.com.br/artigos/21713. 8 maio 2012. Acesso em 15 ago. de 2013

SILVA, Márcio Alberto Gomes. Inquérito Policial: uma análise jurídica e prática da fase pré-processual. Campinas: Millenium, 2012.

TÁVORA, Nestor; ALENCAR, Rosmar Antonni Rodrigues. Curso de Direito Processual Penal. 2a ed. Salvador: Juspodivm, 2009.

TOURINHO FILHO, Fernando da Costa. Processo Penal. 32a ed, vol. 1. São Paulo: Saraiva, 2010.

VALENTE, Manuel Monteiro Guedes. A cientificidade da actuação policial como garante dos direitos humanos. Revista Brasileira de Ciências Policiais. v. 1, n. 1. Brasília: Academia Nacional de Polícia, 2010.

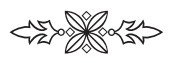

